\title{
THE BUTTERFLY EFFECT IN BOILERPLATE CONTRACT INTERPRETATION
}

\author{
JOHN F. COYLE*
}

I

INTRODUCTION

Legal disputes relating to contract interpretation are frequently conceptualized as one-and-done affairs. A court will adopt what it considers to be a reasonable interpretation of the contract, rule in favor of one of the parties, and decide the case. Neither the judge nor the litigants tend to think overmuch about how the decision will affect other contract users going forward. In cases where the language being interpreted is contract boilerplate, however, past interpretive decisions will inevitably affect future ones. Just as a butterfly flapping its wings in Tokyo can change the weather in London, so too can a judicial decision interpreting boilerplate language alter the meaning of identical language in thousands of other contracts. To speak of the "butterfly effect" in contract interpretation, therefore, is to describe the effect that a single interpretive decision can have on the interests of far-flung parties not involved in the litigation at hand. ${ }^{1}$

This special issue of Law and Contemporary Problems is devoted to exploring the butterfly effect in boilerplate contract interpretation. ${ }^{2}$ This short essay introducing the volume has two objectives. First, it provides a general introduction to the butterfly effect and explains, conceptually, why it is useful to think about boilerplate contract interpretation through this particular lens. Second, it provides summaries of the other articles in the special issue, each of which sheds important light on the workings of the butterfly effect. These contributions, it is hoped, will prove useful to future scholars, judges, and

Copyright $@ 2019$ by John F. Coyle.

This Foreword is also available online at http:/llcp.law.duke.edu/.

* Reef C. Ivey II Distinguished Professor of Law, University of North Carolina at Chapel Hill. Special thanks to Mitu Gulati for his support for this special issue of Law and Contemporary Problems.

1. The butterfly effect is sometimes described as "a component of chaos theory that focuses on the sensitivity of complex systems to small disturbances." Jill Fisch \& Eric Roiter, A Floating NAV for Money Market Funds: Fix or Fantasy?, 2012 U. ILL. L. REV. 1003, 1031 n.197 (2012). In this essay, the term is used to describe how a single judicial decision interpreting contract boilerplate can reshape the meaning of tens of thousands of contracts that contain identical language.

2. This is not the first collection of essays to grapple with the interpretive challenges posed by contract boilerplate. See, e.g., BoILERPLATE: THE Foundation OF MARKET CONTRACTS 143-86 (O. Ben-Shahar ed., 2009). 
legislatures grappling with the interpretive challenges posed by ambiguous contract boilerplate.

II

\section{THE BUTTERFLY EFFECT EXPLAINED}

To understand the significance of the butterfly effect, consider the following scenario. A judge writes a decision assigning a specific meaning to an ambiguous word or phrase that appears in many thousands of contracts. Years later, a different set of parties find themselves involved in litigation implicating the same ambiguous word or phrase. In this new litigation, the judge concludes that that language should be interpreted in precisely the same manner as in the original case decided years before. In future years, other courts presented with the same interpretive question hew closely to the decision rendered by the first two courts.

While this sort of thing happens all the time, it is important to recognize precisely what has transpired. The original interpretive decision recast the meaning of boilerplate language that appears in tens of thousands of existing agreements. This revision occurred without any input from the parties to these other contracts before the fact and without any attempt to notify them of the change after the fact. This is the butterfly effect in boilerplate contract interpretation - the ability of a single interpretive decision to alter the meaning of identical language in thousands of other agreements in one fell swoop.

The butterfly effect in neither good nor bad. It simply is. The effect can, however, generate positive or negative outcomes depending on the quality of the interpretive rule announced in the initial decision. As a general rule, the courts strive to interpret ambiguous contract language to effectuate the parties' intentions. When the language at issue is contract boilerplate that was borrowed wholesale from a prior agreement, however, this task presents obvious challenges. Since the parties never discussed or negotiated this language, it is difficult to unearth any evidence of the specific intent of these particular parties. ${ }^{3}$ In such circumstances, the court must shift gears. Rather than seeking to determine the subjective intent of these particular contracting parties, the courts will instead seek to determine the objective intent of most contracting parties. ${ }^{4}$ The courts will strive, in other words, to develop an interpretive rule that aligns with the preferences of most contract users. ${ }^{5}$

3. See John F. Coyle \& W. Mark. C. Weidemaier, Interpreting Contracts Without Context, 67 AM. U. L. REV. 1673, 1678 (2018) (stating that accuracy as to the parties' intent is "difficult or impossible").

4. See id. ("[E]ven when ostensibly concerned with subjective intent, courts tend to favor evidentiary proxies that are objective in nature."); see also Sharon Steel Corp. v. Chase Manhattan Bank, N.A., 691 F.2d 1039, 1048 (2d Cir. 1982) ("Boilerplate provisions are ... not the consequence of the relationship of particular borrowers and lenders and do not depend upon particularized intentions of the parties to an indenture.").

5. See Charles J. Goetz \& Robert E. Scott, The Mitigation Principle: Toward a General Theory of Contractual Obligation, 69 VA. L. REV. 967, 971 (1983) (suggesting that efficient contract default rules are those that "most" bargainers would prefer). 
When the courts succeed in crafting such a rule, the result is a net benefit for contract users. By interpreting boilerplate language in a manner that conforms to majoritarian expectations, the court minimizes transaction costs because there is no need for contract users to redraft their existing contracts to "correct" an idiosyncratic interpretive decision. ${ }^{6}$ When contracts scholars speak about the network effects that flow from contract boilerplate having a "settled" meaning, they are implicitly referencing the advantages that flow from this positive butterfly effect. ${ }^{7}$

Occasionally, however, the interpretive machinery breaks down. In such cases, the first court to interpret an ambiguous boilerplate provision develops an interpretive rule that is inconsistent with majoritarian expectations. This gives rise to the negative butterfly effect. Contract users must thereafter incur the costs of either redrafting their agreements or convincing a subsequent court to ignore the prior decision in litigation. ${ }^{8}$ These costs are normatively undesirable. They are, however, the logical consequence of a phenomenon that assigns great significance to the first decision to construe a particular piece of boilerplate but that contains no mechanism for evaluating whether the interpretive rule announced in the decision at hand is consistent with the preferences of most contract users.

6. See Richard A. Posner, The Law and Economics of Contract Interpretation, 83 TEX. L. REV. 1581,1581-84 (2005) (stating that the goal of contract interpretation is to reduce transaction costs).

7. See Michelle Boardman, Contra Proferentem: The Allure of Ambiguous Boilerplate, $104 \mathrm{MICH}$. L. REV. 1105, 1112-14 (2006) ("If courts have fleshed out the application of language, a drafter can be confident about its future application."); Marcel Kahan \& Michael Klausner, Standardization and Innovation in Corporate Contracting (or "The Economics of Boilerplate"), 83 VA. L. REV. 713, 718-21 (1997) (discussing the "learning benefits" and "network benefits" parties see when using commonly used language); Tal Kastner \& Ethan J. Lieb, Contract Creep, 107 GEO. L.J. 1277, 1320 (2019) ("Standardized terms in homogenously sophisticated markets invite a particular doctrinal approach that recognizes the efficiency of communicating fixed and reliable meaning."); see also Kolbe v. BAC Home Loans Servicing, LP, 738 F.3d 432, 440 (1st Cir. 2013) ("When a contract uses uniform language that is contained in a large number of contracts, as is the case here, it is a well-established common law principle of contract interpretation that such contracts are interpreted wherever reasonable as treating alike all those similarly situated, without regard to their knowledge or understanding of the standard terms of the writing.’”) (citing RESTATEMENT (SECOND) OF CONTRACTS § 211(2) (AM. LAW INST. 1981)).

8. The negative butterfly effect is particularly pernicious in the context of consumer contracts. Where a court interprets a consumer contract in a manner that favors the company at the expense of the consumer, the language will generally remain unchanged because the consumers are in no position to negotiate a revision. When a court interprets a consumer contract in a manner that favors the consumer, however, the company is well positioned to revise the agreement so as to favor the interests of the company. See David Horton, The Shadow Terms: Contract Procedure and Unilateral Amendments, 57 UCLA L. REV. 605, 608-09 (2010) (observing that consumers have little power in negotiating changes in their contract terms); see also Robin Kar \& Margaret Jane Radin, Pseudo-Contracts and Shared Meaning Analysis, 132 HARV. L. REV. 1135, 1164-65 (2019) (questioning whether certain boilerplate provisions should be considered a part of consumer contracts). 
III

\section{THE Positive ButTerfly EFFECT: An ILlustration}

Boilerplate choice-of-law clauses regularly appear in commercial contracts. ${ }^{9}$ One interpretive question that sometimes arises with respect to these clauses is whether language selecting the "laws" of a particular jurisdiction operates to also select that jurisdiction's conflict-of-laws rules. ${ }^{10}$ Most scholars have argued that these clauses should generally not be interpreted as choosing these rules. Since the whole point of a choice-of-law clause is to provide certainty as to the governing law, so the argument goes, it is unclear why anyone would want to select a body of rules that could lead to the application of the laws of a different jurisdiction. There are, however, a few scattered decisions in which courts have interpreted generic choice-of-law clauses to select the conflicts rules of the chosen jurisdiction. ${ }^{11}$

In 2012, this interpretive question was put before the New York Court of Appeals. ${ }^{12}$ That court was asked to determine whether a choice-of-law clause selecting the "laws" of New York should be read to select that state's conflicts rules. ${ }^{13}$ On the surface, the argument that the clause should be read to select these rules had a certain appeal. While many choice-of-law clauses contain language excluding the conflict-of-laws rules of the chosen state, this particular clause lacked such language. ${ }^{14}$ This fact notwithstanding, the Court of Appeals unanimously held that the clause at issue should be read to exclude the chosen jurisdiction's conflict-of-laws rules. ${ }^{15}$ In the court's words:

It strains credulity that the parties would have chosen to leave the question of the applicable substantive law unanswered and would have desired a court to engage in a complicated conflict-of-laws analysis, delaying resolution of any dispute and increasing litigation expenses. We therefore conclude that parties are not required to expressly exclude New York conflict-of-laws principles in their choice-of-law provision in order to avail themselves of New York substantive law. Indeed, in the event parties wish to emplov New York's conflict-of-laws princibles to determine the applicable substantive

9. See Julian Nyarko, We'll See You in. . Court! The Lack of Arbitration Clauses in International Commercial Contracts, 58 INT”L REV. L. \& ECON. 6, 11 (2018) (“[C]lauses that specify the governing law are very common, appearing in $75 \%$ of the contracts.").

10. See John F. Coyle, The Canons of Construction for Choice-of-Law Clauses, 92 WASH. L. REV. 631, 643-47 (2017) (discussing interpretive rules that the courts apply to resolve this question) [hereinafter Canons].

11. See, e.g., Duskin v. Pennsylvania-Central Airlines Corp. 167 F.2d 727, 732 (6th Cir. 1948) cert. denied, 335 U.S. 829 (1948) (applying the whole law of Pennsylvania); Carlos v. Philips Bus. Sys., Inc., 556 F. Supp. 769, 774 n.4 (E.D.N.Y. 1983) (applying the whole law of New York).

12. IRB-Brasil Resseguros, S.A. v. Inepar Invs., S.A., 20 N.Y.3d 310 (2012).

13. Id. at 312 .

14. See id. at 313 (stating that the agreement was to be "governed by, and... be construed in accordance with, the laws of the State of New York.").

15. Id. at 316 .

16. Id. 
The consensus among scholars, legal commentators, and contract users is that the interpretive rule announced by the New York Court of Appeals is, in fact, the one that is preferred by a majority of contract users. ${ }^{17}$

In the years since this decision was rendered, the positive butterfly effect has ensured that other courts presented with similar choice-of-law clauses construed them in a similar manner. In 2017, the New York Supreme Court was presented with a choice-of-law clause that "omit[ted] the words 'without giving effect to any conflict of law principles under New York law." ${ }^{18}$ Nevertheless, that court held that the "omission of the clause [was] of no moment because parties [were] not required to expressly exclude New York conflict-of-laws principles in their choice-of-law provision in order to avail themselves of New York substantive law." ${ }^{19}$ In 2018, the U.S. District Court for the Southern District of New York reached the same conclusion in a different case. ${ }^{20}$ In its decision, that court observed that New York "appear[ed] to treat as identical a choice-of-law provision designating New York law exclusive of New York conflict-of-law principles and a choice-of-law provision designating New York law without such an exclusion." 21

These cases serve to highlight the positive butterfly effect. The New York Court of Appeals announced an interpretive rule for a standard piece of contract boilerplate that was consistent with majoritarian expectations. Other courts then relied on that decision when interpreting other contracts containing similar language to produce outcomes that were likewise consistent with these expectations. This decision, happily, imposed no costs on other contract users because there was no need for them to redraft their choice-of-law clauses to correct for a judicial mistake.

\section{IV}

\section{THE NeGATIVE BUTTERFLy EFFECT: AN ILLUSTRATION}

Forum selection clauses regularly appear in commercial agreements. ${ }^{22} \mathrm{~A}$ recurring issue relating to the interpretation of these clauses asks whether the parties intended to resolve their dispute in (1) state court, (2) federal court, or

17. See Restatement (SECOND) OF CONFlict of LAws § 187(3) (AM. LAW InST. 1971) ("In the absence of a contrary indication of intention, the reference is to the local law of the state of the chosen law."); Coyle, Canons, supra note 10, at 688. ("It is difficult ... to see why any contracting party would ever want to select the whole law of a jurisdiction to govern their agreement if the goal of the clause is to reduce uncertainty and to ensure a uniform choice of law.").

18. Gottwald v. Sebert, No. 30521(U), slip op. at 8 (N.Y. Sup. Ct. Mar. 20, 2017).

19. Id. (quoting IRB-Brasil Resseguros, S.A. v. Inepar Invs., S.A., 20 N.Y.3d 310, 316 (2012)) (punctuation error in original).

20. In re LIBOR-Based Fin. Instruments Antitrust Litig., 299 F. Supp. 3d 430, 603 (S.D.N.Y. 2018).

21. Id.

22. See Nyarko, supra note 9 , at 11 (stating that forum selection clauses appeared in forty-four percent of contracts in 2008). 
(3) either state or federal court. ${ }^{23}$ Over the years, the courts have developed a number of interpretive rules to help them answer this question. One such rule was announced by the U.S. Court of Appeals for the Tenth Circuit in 1992. ${ }^{24}$

In Milk ' $N$ ' More, Inc. v. Beavert, that court was asked to determine whether a defendant had waived his right to remove a case to federal court when he agreed to a forum selection clause stating that "venue shall be proper under this agreement in Johnson County, Kansas." ${ }^{25}$ The court began its inquiry by noting that the issue presented was "basically one of contract interpretation." ${ }^{26}$ The court's subsequent interpretive analysis, however, left much to be desired. The court first offered the conclusory observation that the wording of the forum selection clause "strongly point[ed] to the state courts of that county." ${ }^{27}$ It then observed that a federal district court in Colorado had previously interpreted a similarly-worded clause to require litigation in state court. ${ }^{28}$ On the basis of these two observations-and nothing else - the Tenth Circuit held that the forum selection clause at issue precluded removal to federal court. The court did not explain why the language in the clause "clear[ly] and unequivocal[ly]" waived the right to remove..$^{29}$ Nor did it explain why the canon requiring ambiguous contract language to be construed against the drafter was inapplicable. ${ }^{30}$ The court simply announced a new interpretive rule - forum selection clauses that select a county as the venue constitute a waiver of the right to remove to federal court-and applied it to the contract.

The years have not been kind to this rule. To date, every other federal circuit to have considered it has rejected it. ${ }^{31}$ The Fifth Circuit has been particularly pointed in its criticism. ${ }^{32}$ Surveys of practicing attorneys, moreover, indicate that this rule does a poor job of effectuating the intent of most contracting parties who

23. See John F. Coyle, Interpreting Forum Selection Clauses, 92 IOWA L. REV. 1791, 1826-30 (2019) (discussing canons of construction affecting the interpretation of forum selection clauses) [hereinafter Interpreting].

24. Milk 'N' More, Inc. v. Beavert, 963 F.2d 1342 (10th Cir. 1992).

25. Id. at $1345-46$.

26. Id. at 1345

27. Id. at 1346.

28. Id. (citing Intermountain Sys., Inc. v. Edsall Constr. Co., 575 F. Supp. 1195, 1198 (D. Colo. 1983)).

29. Id.

30. $I d$.

31. See Simonoff v. Expedia, Inc., 643 F.3d 1202, 1206 (9th Cir. 2011) (holding that when a forum selection clause specifies a county, venue is proper in state or federal court); All. Health Grp. LLC v. Bridging Health Options LLC, 553 F.3d 397, 400-01 (5th Cir. 2008) (rejecting a party's assertion that a forum selection clause specifying a county only included state courts); Global Satellite Commc'n Co. v. Starmill U.K. Ltd., 378 F.3d 1269, 1271 (11th Cir. 2004) (holding that venue was appropriate in either state or federal court when the forum selection clause specified a county).

32. See All. Health Grp. LLC, 553 F.3d at 401 ("[I]t can hardly be said that a reference to 'county' clearly suggests the Harrison County Circuit Court rather than the United States District Court when it has a courthouse in, and jurisdiction over, Harrison County.”). 
draft forum selection clauses. ${ }^{33}$ Nevertheless, the rule continues to be applied by the Tenth Circuit and the district courts within it. ${ }^{34}$ Having concluded-albeit in a conclusory and slapdash fashion - that this contract language has a particular meaning, the Tenth Circuit now views the issue as settled. Any and all future forum selection clauses with similar language that come before the court will be interpreted in the same way.

The consequences of this commitment are illustrated by Excell, Inc. v. Sterling Boiler \& Mechanical, Inc., a case decided by the Tenth Circuit in $1997 .{ }^{35}$ Sterling Boiler \& Mechanical, Inc. was named as defendant in a breach of contract action filed in Colorado state court. ${ }^{36}$ The company wanted to remove the case to federal court but had previously agreed to a forum selection clause that stated that "venue shall lie in the County of El Paso, Colorado." ${ }^{37}$ The company's attorneys tried desperately to persuade the Tenth Circuit that it had never intended to waive its right to remove. They submitted an affidavit signed by the Sterling Boiler employee who had negotiated the contract stating that he understood the clause to permit suit to be brought in either state or federal court. ${ }^{38}$ They argued that the clause was ambiguous and should therefore be construed against the party that had drafted it. ${ }^{39}$ They argued that any waiver of one's right to remove to federal court must be "clear and unequivocal[,]" and that the language in the contract did not meet this standard. ${ }^{40}$ They pointed out that the U.S. District Court for the District of Colorado encompassed all of Colorado, including El Paso County ${ }^{41}$ They did everything they could, in short, to persuade the court that their intent was different than the litigants in the prior case, even though their forum selection clause looked a great deal like the clause in that case.

Their efforts proved unavailing. The Tenth Circuit, citing its prior decision, held that the clause clearly and unequivocally evidenced the parties' intent to litigate their disputes in state court. ${ }^{42}$ To add insult to injury, the court ordered Sterling Boiler to pay the other party's legal fees because it had "little to no basis for seeking removal." ${ }^{43}$ The court held, in essence, that Sterling Boiler was

33. See Coyle, Interpreting, supra note 23, at 1847-50 (observing that most drafters prefer to "preserve the option of going to federal court.").

34. See Triple "S" Operating Co., LLC v. Ezpawn Okla., Inc., 2010 U.S. Dist. LEXIS 65524, at *12 (N.D. Okla. June 30, 2010) (holding that a forum selection clause specifying a county waives the parties' rights to remove to federal court).

35. Excell, Inc. v. Sterling Boiler \& Mech., Inc., 106 F.3d 318, 321 (10th Cir. 1997).

36. Id. at 320 .

37. Id.

38. Defendant's Response to Plaintiff's Motion for Remand to State Court at 6, Excell, Inc. v. Sterling Boiler \& Mech., Inc., 916 F. Supp. 1063 (D. Colo. 1996) (No. 95-B-3030).

39. Opening Brief of Defendant-Appellant at 9, Excell, Inc. v. Sterling Boiler \& Mechanical, Inc., 106 F.3d 318 (10th Cir. 1997) (No. 96-1090).

40. $I d$.

41. Defendant's Response to Plaintiff's Motion for Remand to State Court, supra note 38, at 3.

42. Excell, 106 F.3d at 321.

43. Id. at 322 . 
wasting everyone's time. The Tenth Circuit had already decided what these words meant. If the parties had wanted a different result, they should have used different words.

This case serves to highlight the negative butterfly effect. ${ }^{44}$ The Tenth Circuit announced an interpretive rule that was arguably inconsistent with majoritarian expectations. That court then relied on that rule in a subsequent case containing similar language to produce a decision that was similarly inconsistent with these expectations. Significantly, it did so notwithstanding a barrage of evidence that would have supported a contrary outcome. As a consequence of this decision, contracting parties in the Tenth Circuit must now incur the drafting costs of rewriting their agreements or, alternatively, incur the litigation costs of seeking to persuade future court to set aside this particular interpretive rule.

\section{V}

\section{ACCEnTUAting THE Positive}

In light of the foregoing discussion, the question that naturally arises is what, if anything, the courts can do to maximize the likelihood that their readings of ambiguous contract boilerplate align with majoritarian expectations in the first instance. Put differently, how can the courts maximize the chances that their interpretive rules reflect the preferences of most contract users?

While there are several strategies that the courts might consider, they all derive from the same basic insight-judicial decisions interpreting contract boilerplate have third-party effects. In order to ensure that these effects are positive rather than negative, the courts should actively solicit input from neutral third parties whenever they are called upon to interpret contract boilerplate for the first time. ${ }^{45}$ They should not simply rely on the representations of the litigants

44. Another example of the negative butterfly effect can be found in litigation relating to the meaning of the pari passu clause in sovereign debt agreements. In 2000, a court in Belgium ruled that this clause "meant that a sovereign could not make preferential payments to any of its creditors whose debt ranked pari passu with the debt that they held." Stephen J. Choi \& Mitu Gulati, Contract as Statute, 104 MICH. L. REV. 1129, 1134 (2006). Courts in other nations were subsequently urged to adopt this interpretation - which benefited investors at the expense of sovereigns - in litigation with sovereigns whose debt agreements contained similar language. Id. at 1135. Although this interpretation was viewed as preposterous by many sovereign debt attorneys, it was subsequently adopted by a number of judges in the United States. Stephen J. Choi, Mitu Gulati \& Robert C. Scott, The Black Hole Problem in Commercial Boilerplate, 67 DUKE L.J. 1, 20-21 (2018). While it is certainly possible that this result would have occurred regardless of how the Belgian court ruled in the original case, most scholars believe that that decision played a role in shaping the decisions rendered by later courts. See, e.g., Lee C. Buchheit \& Jeremiah S. Pam, The Pari Passu Clause in Sovereign Debt Instruments, 53 EMORY L.J. 869, 879 ("[T]he Belgian Court's decision was significant: the ratable payment interpretation of the pari passu clause had been unleashed.").

45. See Choi \& Gulati, supra note 44, at 1170 (suggesting that the International Swap and Derivatives Association be consulted as an independent authority to resolve ambiguities in the text of a standard swaps contract). When dealing with industry organizations, it is essential that the organization in question be truly neutral in its perspective. Deferring to an interpretation proffered by the Insurance 
and their hired experts in the case at hand. This is because party representations are inevitably self-serving; each litigant will argue that its preferred interpretation is the one that is favored by the majority of contract users. ${ }^{46}$ In order to maximize the likelihood that it will produce a true majoritarian default rule, in short, the judge should elicit input from independent sources before rendering an interpretive decision of first impression that may effectively rewrite the language in many thousands of private agreements.

In some cases, this strategy may involve appointing an independent expert to testify on an interpretive issue. ${ }^{47}$ In others, it may involve appointing an independent attorney or legal organization to file an amicus brief that addresses the interpretive question. ${ }^{48}$ In still others, the courts could look to surveys of practicing attorneys or contract users that shed light on how these parties want ambiguous contract boilerplate to be construed. Omri Ben-Shahar and Lior Strahilevitz, for example, have conducted surveys of consumers to gain insights into how courts should interpret certain provisions in consumer contracts. ${ }^{49}$ In my own work, I have conducted surveys of practicing attorneys to gain insights into how the courts should interpret dispute-resolution provisions in business contracts. ${ }^{50}$ While such surveys will obviously not be available in every case, these instruments are arguably a more reliable gauge as to third-party views than the representations made by litigants, their experts, or the judge's own armchair intuitions as to meaning of a particular piece of boilerplate.

\section{VI}

\section{COUNTERACTING THE NEGATIVE}

When the interpretive machinery breaks down, and a court renders an interpretive decision that is inconsistent with majoritarian preferences, there are

Services Office, for example, would not be appropriate because this organization principally represents insurance companies.

46. In the litigation relating to the pari passu clause referenced above, for example, the investors paid Andreas Lowenfeld, a well-known U.S. professor of international law, to prepare an affidavit in support of their interpretation to a Belgian court. Although there was no New York precedent on point, and although subsequent research was to reveal that most sovereign debt lawyers profoundly disagreed with this interpretation, Professor Lowenfeld's affidavit "admitted no shard of doubt about either the meaning of the pari passu clause in a sovereign debt instrument or its effect on creditor remedies." Buchheit \& Pam, supra note 44, at 878 . It is probable that an affidavit submitted by an independent expert would have offered a more balanced take on this issue.

47. This action is expressly permitted by the Federal Rules of Evidence, which provide that the "court may appoint any expert ... of its own choosing." See FED. R. EVID. 706(a).

48. See Katherine Shaw, Friends of the Court: Evaluating the Supreme Court's Amicus Invitations, 101 CORNELL L. REV. 1533, 1548 n.68 (2016) (discussing cases where the Supreme Court has appointed an amicus curiae "to advance a particular argument, in a case pending before the court" so as to permit the Court to "decide the case satisfied that the relevant issues have been fully aired").

49. See generally Omri Ben-Shahar \& Lior Jacob Strahilevitz, Interpreting Contracts Via Surveys and Experiments, 92 N.Y.U. L. REV. 1753 (2017).

50. See generally Coyle, Canons, supra note 10; Coyle, Interpreting, supra note 23. 
several ways by which the negative consequences that would otherwise result from that decision might be counteracted. First, private parties could contract around the decision by redrafting the language in their agreement. This privateordering strategy represents the simplest and most straightforward solution to an idiosyncratic interpretive decision. ${ }^{51}$ Like the other strategies discussed in this section, however, it imposes costs on private actors that could be avoided if the courts rendered a decision that conformed to majoritarian expectations in the first instance. This private-ordering strategy is also not available to parties who are unaware of the original decision.

As an alternative, one might seek to overturn the original decision by persuading a subsequent court that the interpretive rule laid down in that decision is contrary to the preferences of most contract users. ${ }^{52}$ This strategy is most likely to succeed when there has been some intervening event, such as the publication of a new Restatement specifically rejecting the interpretative rule at issue. New objective evidence, such as a survey showing that the interpretive rule is inconsistent with the expectations of a majority of contract users, may also assist in realizing this goal. In many cases, however, the strategy will fail because the new court will invoke the principle of stare decisis and refuse to revisit the rationale underlying the original decision.

Third, one could petition the state legislature to enact a statute that preempts the original interpretive decision and lays down a new interpretive rule for the courts to apply to contracts going forward. While state statutes assigning a meaning to particular contract language are not exactly common, neither are they unknown. California has enacted a statute that lays down interpretive rules for its courts to apply when interpreting contracts of indemnity. ${ }^{53}$ Virginia has enacted a statute directing its courts to construe phrases such as "exclusive license" and "all possible rights and for all media" in a specific manner when they appear in licensing agreements. ${ }^{54}$ And West Virginia has enacted a statute that sought to "correct a misinterpretation and misapplication of the law" in a prior interpretive decision rendered by that state's supreme court. ${ }^{55}$ While this particular strategy presents challenges-it is no easy feat to persuade a state legislature to enact a statute-it represents yet another avenue by which to counteract flawed interpretive decisions that impose costs on third parties via the negative butterfly effect.

51. In the past decade, for example, several universities have redrafted their standard employment agreements in response to an adverse interpretive decision rendered by the Federal Circuit involving a patent license. See Robert M. Yeh, The Public Paid for the Invention: Who Owns It?, 27 BERKELEY TECH. L.J. 453, 468-70 (2012) (discussing Bd. of Trs. of the Leland Stanford Junior Univ. v. Roche Molecular Sys., 583 F.3d 832, 841-42 (Fed. Cir. 2009)).

52. See supra notes 35-43 and accompanying text (discussing unsuccessful efforts on the part of Sterling Boiler to persuade the Tenth Circuit to revisit its earlier interpretive decision).

53. Cal. Civ. Code $\S 2778$ (West 1872); see also N.D. Cent. Code Ann. § 22-02-07 (West 1877).

54. Va. Code Ann. § 59.1-503.7(e) (West 2004).

55. W. Va. Code Ann. § 33-6-30(c) (West 2002). 


\section{CONTRIBUTIONS TO THE SPECIAL ISSUE}

Each of the articles prepared for this special issue of Law and Contemporary Problems grapples with one or more aspects of the butterfly effect described above. A brief summary of each contribution appears below.

In Risk-Averse Contract Interpretation, Aditi Bagchi argues that courts should always take standard market terms into account when interpreting ambiguous boilerplate contract language..$^{56}$ This approach acknowledges the effects that such decisions have on third parties not involved in the litigation at hand. If courts look to published prices, formal trade association guidance, and agreements filed with the Securities Exchange Commission, then it is much less likely that they will interpret a particular word or phrase in a manner that is inconsistent with majoritarian expectations. The end result is an interpretive methodology that maximizes the likelihood that a given decision will generate a positive butterfly effect.

In The Unpredictability of Insurance Interpretation, Michelle Boardman explores the butterfly effect in the context of insurance contracts. ${ }^{57}$ She argues, first, that insurance companies will sometimes choose not to redraft their agreements in response to an adverse interpretive decision. In these cases, they simply let the negative butterfly effect have its way and charge more for a given policy. Second, she argues that sometimes insurers will respond to adverse decisions by redrafting their contracts to exclude coverage. Third, and finally, she argues that in some cases it may be impossible for insurers to redraft their policies in a manner that will satisfactorily address an adverse interpretive decision, because there is no practical way to make the language comprehensible to the average policyholder.

In The Butterfly Effect in Interpreting Insurance Policies, Chris French also explores the butterfly effect in the context of insurance contracts. ${ }^{58} \mathrm{He}$ shows how insurance companies strategically decide when-and when not-to litigate in order to use the butterfly effect to their advantage. An insurance company may, for example, preemptively seek a declaratory judgment in a favorable jurisdiction stating that a specific word in a policy has a particular meaning. If the court renders a favorable interpretive decision, the insurance company will then invoke that decision in future litigation implicating the same policy language. The article also discusses how insurance companies redraft sections of their policies in response to adverse interpretive decisions in order to negate the butterfly effect that would otherwise prove helpful to policyholders in future litigation. 1.

56. Aditi Bagchi, Risk-Averse Contract Interpretation, 82 LAW \& CONTEMP. ProBS., no. 4, 2019, at

57. Michelle E. Boardman, The Unpredictable Effects of Insurance Interpretation, 82 LAW \& CONTEMP. PROBS., no. 4, 2019, at 27.

58. Christopher C. French, The Butterfly Effect in Interpreting Insurance Policies, 82 LAW \& CONTEMP. PROBS., no. 4, 2019, at 47. 
In Boilerplate No Contest Clauses, David Horton and Reid Weisbord note that boilerplate no contest clauses are quite common in wills. ${ }^{59}$ They discuss a decision by the California Supreme Court that misinterpreted one of these clauses and imposed significant costs on beneficiaries with little in the way of corresponding benefit. They then show how a statute enacted by the California legislature effectively overruled this decision and established a new interpretive default rule that was more in line with majoritarian expectations. This article thus serves to highlight the utility of legislative intervention as a potential means of correcting mistakes when the interpretive machinery for assigning meaning to boilerplate language breaks down.

In Boilerplate and Party Intent, Greg Klass argues that it is sometimes appropriate to disregard party intent altogether when interpreting contract boilerplate. ${ }^{60}$ When the government mandates that a particular clause be included in a certain type of agreement, for example, Klass argues that the government's understanding of the language should always prevail. Similarly, in markets that require uniform contract terms to operate properly, he argues that courts should seek to achieve uniformity in contract interpretation and should not concern themselves overmuch with the intent of the parties.

In Consumertarian Default Rules, Lior Strahilevitz and Jamie Luguri argue that courts and legislatures should adopt "consumertarian" default rules. ${ }^{61} \mathrm{~A}$ consumertarian default rule is a variety of penalty default rule that fills in missing terms of a contract based on the expectations of consumers writ large. In cases involving ambiguous language in contracts between sophisticated and unsophisticated entities, for example, the consumertarian approach counsels in favor of surveying lay respondents about what the contractual text means and adopting the meaning preferred by the majority of consumers where a consensus emerges. Once this consumer-friendly interpretation is adopted with respect to a specific piece of contract boilerplate, the butterfly effect ensures that the interpretation will benefit other consumers in future cases.

In Crisis Construction in Contract Boilerplate, Emily Strauss identifies a puzzle. ${ }^{62}$ In mortgage-backed-securities litigation arising out of the financial crisis that began in 2008, several courts construed specific pieces of contract boilerplate in a manner that was flatly inconsistent with the language in these provisions. To solve this puzzle, Strauss shows how several early cases involving different contracts with different language were construed in a particular way by the courts. She then shows how the courts in subsequent cases followed the interpretive footsteps of the original court even though the language in the

59. David Horton \& Reid Kress Weisbord, Boilerplate No Contest Clauses, 82 LAW \& CONTEMP. ProBs., no. 4, 2019, at 69.

60. Gregory Klass, Boilerplate and Party Intent, 82 LAW \& CONTEMP. PROBS., no. 4, 2019, at 105.

61. Lior Jacob Strahilevitz \& Jamie Luguri, Consumertarian Default Rules, 82 LAW \& CONTEMP. PROBS., no. 4, 2019, at 139.

62. Emily Strauss, Crisis Construction in Contract Boilerplate, 82 LAW \& CONTEMP. PROBS., no. 4, 2019 , at 163 . 
subsequent contracts was different. In these cases, the butterfly effect was powerful enough to impact later interpretive decisions involving contract language that bore little resemblance to that in the original cases.

Finally, in Law, Lawyers, and Self-Governance During the Heyday of the London Stock Exchange, Mark Weidemaier explores the sources of friction between the London Stock Exchange (LSE) and the English courts in the latenineteenth and early-twentieth centuries with respect to the proper interpretation of the rules promulgated by the LSE. ${ }^{63}$ Contracts between brokers and customers on the LSE were governed by these rules even though the LSE did not promulgate standard-form contracts expressly incorporating them. When the English courts were called upon to construe these rules, they occasionally rendered interpretations that were inconsistent with those of the trading community. In some cases, the LSE undertook to revise its rules to overrule these interpretive decisions to avoid a negative butterfly effect. In others, however, inertia prevailed and the LSE acquiesced to the interpretive rule announced by the courts in order to avoid putting itself into direct conflict with the judiciary.

Together, these articles showcase the important role that contract boilerplate plays in contemporary legal practice. In so doing, they provide a compelling account of why it is useful to think about the process of interpreting that boilerplate through this lens.

63. W. Mark C. Weidemaier, Law, Lawyers, and Self-Governance During the Heyday of the London Stock Exchange, 82 LAW \& CONTEMP. PROBS., no. 4, 2019, at 195. 